\title{
Thermal stability of magnesium fabricated by combination of mechanical milling and spark plasma sintering
}

\begin{abstract}
Masahiro KUBOTA ${ }^{1}$ and Toshiki HAGINO ${ }^{2}$
Pure magnesium powders together with $0.5 \mathrm{~g}$ of process control agent were mechanically milled (MM) using a planetary type of ball mill with different processing times. MMed powders were consolidated into bulk materials by the spark plasma sintering (SPS). Changes in hardness and solid-state reactions of the SPS materials before and after isochronal and isothermal heating at $473 \mathrm{~K}, 523 \mathrm{~K}$ and $573 \mathrm{~K}$ have been examined by hardness measurements and an X-ray diffraction. Enhanced hardness was observed in the SPS materials fabricated from MMed $32 \mathrm{~h}$ powder after heating at $523 \mathrm{~K}$ for $8 \mathrm{~h}$. The value of Vickers hardness in the SPS materials during heating at $523 \mathrm{~K}$ increased from 48 to $91 \mathrm{HV}$, suggesting that hardening ability was $43 \mathrm{HV}$. Solid-state reaction was clearly observed in all SPS materials fabricated from MMed powders produced with the different MM time after heating at $473 \mathrm{~K}$, $523 \mathrm{~K}$ and $573 \mathrm{~K}$. The contribution for enhancement of hardness in the SPS materials was attributable from formation of $\mathrm{MgO}, \mathrm{MgH}_{2}$, and $\mathrm{Mg}(\mathrm{OH})_{2}$, typically from $\mathrm{MgO}$. The thermal stability of pure magnesium can be improved by MM-SPS process.
\end{abstract}

(Received March 29, 2019 Accepted August 20, 2019)

Keywords: magnesium; powder metallurgy; mechanical milling; spark plasma sintering; solid-state reaction

\section{1. 緒言}

地球温暖化対策推進法で示された低炭素社会を構築するた めに, 輸送機械産業においては, 燃費向上を目的として構造 材料の軽量化が進められている。実用金属材料中, 密度が最 も小さく，比強度抄よび比剛性に優れるマグネシウム合金が 注目されているが, 鉄鋼材料やアルミニウム合金と比較し て, 強度や剛性だけでなく耐熱性も低いため構造材料として の適用が制限されている。

マグネシウムの強度特性㧍よび耐熱性を改善する方法と して溶解鋳造法によるレアメタルとの合金化と析出硬化を 組み合わせる手法 ${ }^{1)}$,2) が, Rokhlinによって詳細に報告 ${ }^{3)}$ さ れている。日本では，1950年代にセリウム（Ce）を添加し た $\mathrm{Mg}-\mathrm{Ce}$ 合金の析出硬化が報告 ${ }^{4)} さ れ て お り ， 1970$ 年代に 大森らによって $\mathrm{Mg}-\mathrm{Ce}$ 合金の析出組織について電子顕微鏡 による直接観察が実施されている ${ }^{5), 6)}$ 。近年では, 重希土 類元素のガドリニウム $(\mathrm{Gd})^{7,8)}$ ，テルビウム $(\mathrm{Tb})^{7)}$ また はジスプロシウム $(\mathrm{Dy})^{8)}$ を含むマグネシウム合金で優れ た時効硬化特性が得られること，523Kまでの耐熱性が飛躍 的に改善されることが報告 ${ }^{7), 8)}$ されている。例えば $523 \mathrm{~K} に$
扮ける $\mathrm{Mg}-20 \mathrm{mass} \% \mathrm{Gd}$ 合金（引張強さ：306 MPa，耐力： $236 \mathrm{MPa})^{7,8)}, \mathrm{Mg}-20$ mass $\% \mathrm{~Tb}$ 合金 (引張強さ: $280 \mathrm{MPa}$, 耐 力: $228 \mathrm{MPa})^{7)}$ 抢よび $\mathrm{Mg}-20$ mass $\%$ Dy 合金 (引張強さ： $275 \mathrm{MPa}$, 耐力 : $201 \mathrm{MPa})^{8)}$ の引張強さ掞よび耐力は, 既存 の耐熱マグネシウム合金として知られている $\mathrm{Mg}-\mathrm{Y}-\mathrm{Nd}$ 系の WE54A 合金 (引張強さ : $225 \mathrm{MPa}$, 耐力 : $170 \mathrm{MPa})^{9)}$ より優 れた值を示している。また, Mg- $\mathrm{Gd}$ 系扮よび $\mathrm{Mg}$-Dy系合金 ヘイットリウム $(\mathrm{Y})$ 扔よびネオジム $(\mathrm{Nd})^{10)}$ の複合添加, そして $\mathrm{Nd}$ とジルコニウム $(\mathrm{Zr})$ の複合添加 ${ }^{11)}$ は, 耐熱性を さらに高めることが報告 ${ }^{10)}$,11) されている。しかし，レアメ タルを用いたこれらの合金化はコストが高く，かつ長期的な 元素戦略の視点に立つとレアメタルフリーのマグネシウム合 金の開発が望まれている。この観点から，合金開発に関す る概念が小島によってまとめられており ${ }^{12)}$ ，最近では， $\mathrm{Mg}_{-}$ $\mathrm{Zn}-\mathrm{Ca}$ 系合金 ${ }^{13)}$ 抒よび $\mathrm{Mg}-\mathrm{Al}-\mathrm{Ca}$ 系合金 ${ }^{14)}$ 17) が低コス卜 化や難燃性の観点から注目されている。これらの合金では, 過飽和固溶体からの析出により規則的な G. P.ゾーンが形成 され ${ }^{14), 15)}$ ，特に, Mg-3.6Al-3.3Ca-0.4Mn (mass\%) 合金では, 押出まま材 $(623 \mathrm{~K})$ でも, ナノサイズの Al-Ca系板状析出 物抢よびAl-Ca-Mn系球状析出物が複相組織を呈し, それら

\footnotetext{
${ }^{1}$ 日本大学生産工学部機械工学科（广275-8575 千葉県習志野市泉町 1-2-1） Department of Mechanical Engineering, College of Industrial Technology, Nihon University (1-2-1 Izumi-cho, Narashino-shi, Chiba 275-8575)

${ }^{2}$ 日本大学大学院生産工学研究科機械工学専攻（習志野市）〔現在：東芝プラントシステム株式会社〕 Graduate School of Industrial Technology, Nihon University (Narashino-shi, Chiba)〔Present: Toshiba Plant Systems \& Services Corporation〕

* 責任著者E-mail: kubota.masahiro@nihon-u.ac.jp
} 
の強化相により，室温でレアメタルを含む合金と同等以上の 引張強さ $420 \mathrm{MPa}$ ，耐力 $410 \mathrm{MPa}$ が得られている ${ }^{18)}$ 。

一方で, メカニカルミリング (Mechanical Milling: MM) と放電プラズマ焼結（Spark Plasma Sintering: SPS）を組み 合わせた粉末治金法の MM-SPS プロセスにより合金元素 を添加せずに高硬度かつ熱的安定性に優れた純アルミニウ ム ${ }^{19), 20)}$ および純チタン ${ }^{21) ~ 23)}$ が創製できることが報告され ている。高機能化されたこれらの特性は，MM処理の際に軽 金属粉末が容器内へ過度に固着する焼付きを防止，かつ緩和 するためにミリング助剤 (Process Control Agent: PCA）とし て添加されているステアリン酸 $\left(\mathrm{CH}_{3}\left(\mathrm{CH}_{2}\right)_{16} \mathrm{COOH}\right)$ が重要 な役割を担っている。すなわち，ユビキタス元素で構成され ているステアリン酸は, MM処理中に母材である軽金属粉末 中に微細かつ均一に分散し，MM処理中または，その後の熱 処理によって固相反応が誘起され, 強化相が in situ生成され ることに起因している 20) 24)。さらに，活性なアルミニウム やチタンでは, 粉末の表面に形成されている酸化膜が MM処 理中に微細に粉砕され，母材中に均質に分散させることも可 能である。したがって，MMプロセスによって，軽金属粉末 に対して分散強化を発現できる条件が整うことで，高温強度 の改善が図られる可能性を秘めている20) 24)

MMプロセスによって高機能化された粉末の固化成形に は, 従来の熱間押出加工，ホットプレス焼結法や熱間等方圧 焼結法と比較して，火花放電による放電衝撃圧とジュール熱 の両方によって低温, かつ短時間でのバルク化が達成でき るSPS プロセスが注目されている ${ }^{25)}$ 27)。得られるバルク材 の最終形状は，焼結に使用する黒鉛金型の形状に制約を受け るが，MMプロセスで得られた粉末が有する微細な結晶粒お よび分散する粒子の粗大化を抑制した固化成形が可能であ る ${ }^{25)}$ 27) 。さらに，焼結中に固相反応が誘起され，強化相が in situ生成することも期待できる ${ }^{20) 〜 24) 。 ~}$

既報 ${ }^{28)}$ では，MM-SPS プロセスを純マグネシウムに適用 し，MMプロセス条件と作製したバルク材の硬さとの関係 を構築し, AZ31 マグネシウム合金O材と同等レベルの硬さ を得るためのMM-SPS プロセス条件を明らかにした。特に, MM処理によって純マグネシウム粉末に導入できる転位量 ${ }^{28)}$ と冷間加工によって板材に導入された転位量 ${ }^{29)} に$ に限界があ ること，粉末治金法から作製された粉末 ${ }^{28)}$ と溶解鋳造法か ら作製された板材 ${ }^{29)}$ に対する加工硬化の割合は同レベルで あることが示されている。すなわち，転位の導入が可能なプ ロセスとして知られている MM処理や冷間加工による強加 工を施しても，純マグネシウムの加工硬化による硬さの向上 の割合は，小さいことが示唆されている。

また，これまでに粉末治金法で作製した純マグネシウム の熱的安定性を評価した報告は, 著者の知る限り見当たら ない。したがって, 本研究では既報 ${ }^{28)}$ で見出された最適な PCA 添加量 $0.50 \mathrm{~g}$ に着目し, MM-SPS プロセスを純マグネシ ウムに適用し，作製したSPS材をまずはじめに熱処理によっ て固相反応が誘起するかどうかを調べた。次にSPS材の熱処 理に対する熱的安定性の評価を硬さ試験から試みた。最後 に, SPS 材の熱的安定性と固相反応によって生成する化合物 相に及ぼす MM処理時間の影響を調査した。すなわち，本研 究の目的はMM-SPS プロセスで作製した純マグネシウムの 熱的安定性とプロセス条件との関係を構築することである。

\section{2. 実験方法}

\section{1 供試材の作製}

本研究では, 既報 ${ }^{28)}$ と同様の純マグネシウム粉末（純 度 $99.91 \%$, 平均粒子径 $384.5 \mu \mathrm{m}$ ）を使用し, 精密天秤によ り $25.0 \mathrm{~g}$, さらにPCAとして添加するステアリン酸を $0.50 \mathrm{~g}$ 秤量し, これらの粉末と直径 $10 \mathrm{~mm}$ の高クロム鋼製ボール $400 \mathrm{~g}$ を内容量 $500 \mathrm{~mL}$ の高クロム鋼製容器に装入した。そ の際, グローブボックス中で容器内をアルゴン（純度：

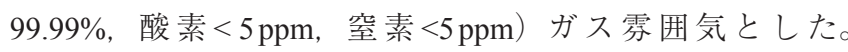
MM処理には遊星型ボールミル（Fritsch, P-5）を用い, 公転 速度 $200 \mathrm{rpm}$ で $2 \mathrm{~h}, 4 \mathrm{~h}, 8 \mathrm{~h}, 16 \mathrm{~h}, 32 \mathrm{~h}$ および $64 \mathrm{~h}$ 処理した ${ }^{28)}$ 。

得られた MM粉末は, SPS 装置 (住友石炭鉱業 (株), SPS-1050）を用いて固化成形した。作製条件は，既報 ${ }^{28)}$ で 示した通りである。すなわち, 外径 $50 \mathrm{~mm} \times$ 内径 $20 \mathrm{~mm} \times$ 高 さ $40 \mathrm{~mm}$ の黒鉛金型に MM粉末 $4 \mathrm{~g}$ を装入し, チャンバー内 の真空度を $20 \mathrm{~Pa}$ 程度に保ち, 黒鉛パンチで圧力 $15.4 \mathrm{kN}$ を加 えて, 焼結温度 $723 \mathrm{~K}$, 昇温速度 $1.25 \mathrm{~K} / \mathrm{s}$, 保持時間 $180 \mathrm{~s}$ で 高さ約 $8 \mathrm{~mm}$ のバルク（SPS）材を作製した。また，カーボ ン紙を黒鉛金型の内部に設置し，離型剤として使用した。

各SPS材の熱的安定性を評価するために電気炉を用いて大 気中で, $473 \mathrm{~K}, 523 \mathrm{~K}$ およ゙ $573 \mathrm{~K}$ の 3 条件で熱処理した。熱 処理時間は, $0.5 \mathrm{~h}$ から最大 $8 \mathrm{~h}$ 保持した。

\section{2 材料特性の評価}

SPS 材の化合物相は, X線回折装置 (株) 島津製作 所，XRD-610）を用いて同定した。測定は, $\mathrm{CuK} \alpha$ 線（ $=1.54056 \AA$ ）を用いて管電流 $60 \mathrm{~mA}$, 管電圧 $40 \mathrm{kV}$ で回折速 度 $1.66 \times 10^{-2} \% \mathrm{~s}$ および回折角度 $2 \theta$ が $20 \sim 80^{\circ}$ の範囲で行った。 SPS 材の加圧面をエメリー紙で研磨後, さらにバフ研磨し, 測定に供した。SPS材の硬さは, 加圧面をエメリー紙で研 磨後, バフ研磨し, ビッカース硬度計（株)アカシ， HV-115） を用いて，荷重 $1 \mathrm{~kg}$, 保持時間 $20 \mathrm{~s}$ で 10 ポイント測定した。 測定した 10 ポイントの上位 1 ポイント, 下位 1 ポイントの值 を除いた 8 ポイントの平均值を硬さとした。SPS材の組織は, エメリー紙で研磨後, バフ研磨し, 腐食液（蒸留水：90\%, 硝酸：10\%) でエッチングし, 光学顕微鏡（オリンパス(株), BX60M）で観察した。

\section{3. 実験 結果}

\section{1 等時加熱の影響}

Fig. 1 に各 SPS 材を $473 \mathrm{~K}, 523 \mathrm{~K}$ および $573 \mathrm{~K} て ゙$ 等時加 熱（1h）後, 硬さを室温で測定した結果を示す。なお, 横 軸の As-sintered と $473 \mathrm{~K}$ に連続性はない。加熱前の MM $2 \mathrm{~h}$ お よびMM 8h SPS 材の硬さは, MM処理をしていない純マグ ネシウム粉末から固化成形したSPS材よりも低い值を示した が，MM 4h, MM 16h, MM 32h およびMM 64h SPS 材は，高 い值を示した ${ }^{28)}$ 。MM 16h, MM 32h およびMM 64h SPS 材 の加熱前の硬さに顕著な差は認められなかった。これらの 結果は, 既報 ${ }^{28)}$ でも示されているように, MM処理による 純マグネシウム粉末へのひずみの導入が小さいこと, さら に，導入されたひずみがSPS 焼結中に回復することに起因し ている ${ }^{29)}$ 。473Kにおける加熱により, 各SPS 材の硬さは加

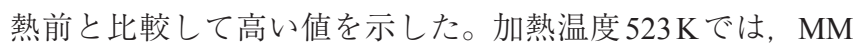
$32 \mathrm{~h} \mathrm{SPS}$ 材の硬さが加熱前と比較して約 2 倍の $86 \mathrm{HV}$ を示し 


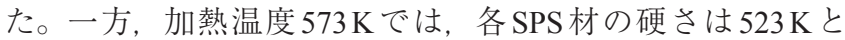
比較して軟化傾向を示した。各SPS材の硬さの測定誤差は, $\pm 8 \mathrm{HV}$ 以内であった。

硬さが最も顕著に増加したMM $32 \mathrm{~h} \mathrm{SPS}$ 材の各温度にお ける等時加熱（1h）に対するX線回折パターンをFig. 2 に 示す。粉末および加熱前のSPS材では, 純マグネシウムか らの回折ピークのみが同定 ${ }^{30)}$ された。一方，473K, $523 \mathrm{~K}$ および $573 \mathrm{~K} て ゙$ 加熱したSPS材は，いずれもマグネシウム 以外の回折ピークが認められ, それらは $\mathrm{MgO}^{31)}, \mathrm{MgH}_{2}{ }^{32)}$ および $\mathrm{Mg}(\mathrm{OH})_{2}{ }^{33)}$ と同定された。これらの結果から等時 加熱中に固相反応が誘起され，生成した化合物によって硬 さが増加したと考えられる。さらに, 回折ピーク強度は,

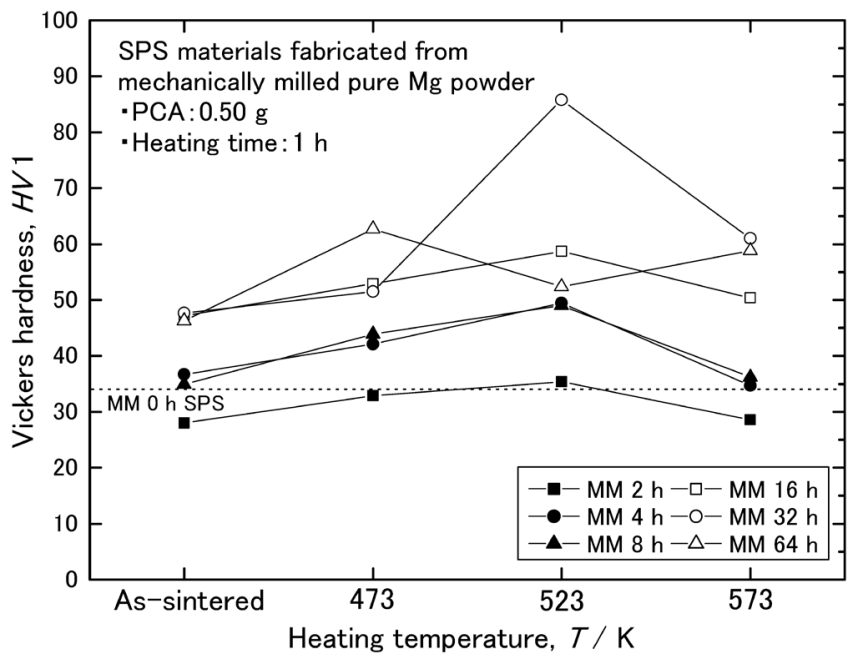

Fig. 1 Changes in Vickers hardness for SPS materials fabricated from mechanically milled pure $\mathrm{Mg}$ powder with addition of $0.50 \mathrm{~g}$ PCA after isochronal heating at various temperatures for $1 \mathrm{~h}$.
$\mathrm{MgH}_{2}<\mathrm{Mg}(\mathrm{OH})_{2}<\mathrm{MgO}$ の順に高くなっている。この結果は, 主に $\mathrm{MgO}$ の生成が硬さへ寄与していることを示唆している が，詳細な検討が必要である。また，加熱温度を変化させて も回折パターンは，ほぼ同様のプロファイルが得られてお り，固相反応による生成物は加熱温度（加熱 $1 \mathrm{~h} ） に$ 依存し ないことも示唆された。

$\mathrm{MgH}_{2}$ の生成は, $\mathrm{MM}$ 処理中に純マグネシウム粉末とステ アリン酸を構成している水素との間で固相反応が誘起するこ とに起因していると考えられる。また，加熱前のSPS材では 純マグネシウム粉末の表面に形成されていると推測される 酸化膜 $\mathrm{MgO}$ および $\mathrm{Mg}(\mathrm{OH})_{2}$ が同定されていなかった。した がって，ステアリン酸に含まれる酸素および水素がMM処 理中に粉末内部に取り込まれ，その後の焼結によって得られ たSPS 材を加熱することによって固相反応が誘起され $\mathrm{MgO}$ および $\mathrm{Mg}(\mathrm{OH})_{2}$ が生成したと考えられる。一方, $\mathrm{MgO}$ およ び $\mathrm{Mg}(\mathrm{OH})_{2}$ の生成は大気中に含まれる水分によって形成さ れる可能性も考えられる。この推測を検証するためにステア リン酸を添加せずに純マグネシウム粉末の MM処理を試み たが，粉末が容器内に固着し，健全な粉末を作製することが できなかった。したがって，この推論の検証を行うことがで きなかった。しかし，MM処理前の純マグネシウム粉末から 同条件で作製したSPS材を同条件で加熱しても化合物は生成 されなかったことから，固相反応によって生成するこれらの 化合物の構成元素の供給源はステアリン酸であると断定でき る。すなわち, $\mathrm{MgO}, \mathrm{MgH}_{2}$ および $\mathrm{Mg}(\mathrm{OH})_{2}$ の生成には，水 素や酸素を含むステアリン酸を伴ったMM-SPS プロセスお よびその後の加熱が必要であることが明らかとなった。

各 MM処理時間によって作製されたSPS材を各温度で等 時加熱（1h）後に固相反応により生成する化合物相をX線 回折で同定した結果を Table 1 に示す。加熱温度 $473 \mathrm{~K}$ およ び523Kに関して，MM 2h, MM 4hおよびMM 64h SPS 材は,

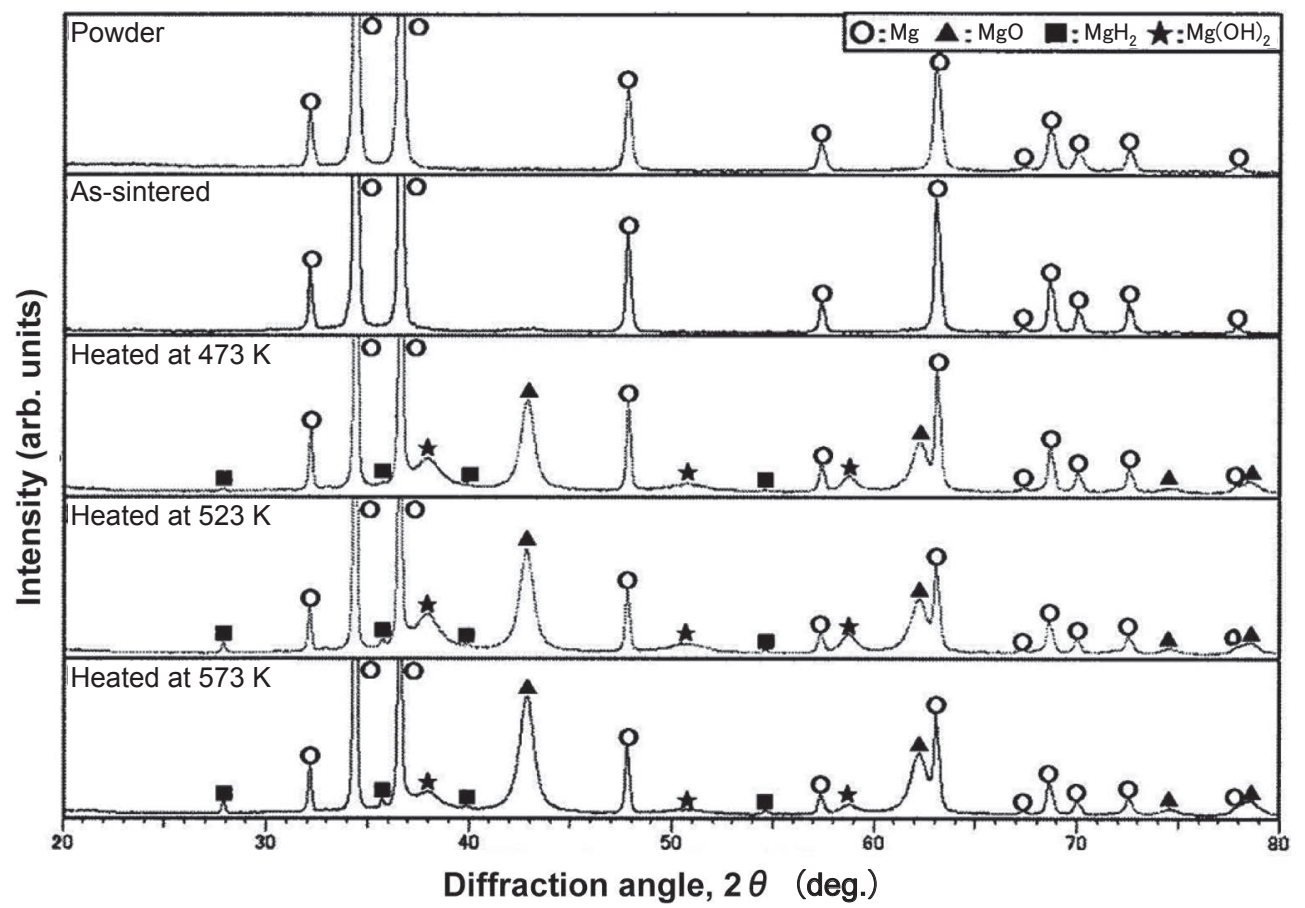

Fig. 2 X-ray diffraction patterns recorded from SPS materials fabricated from mechanically milled $32 \mathrm{~h}$ pure Mg powder with addition of $0.50 \mathrm{~g}$ PCA after isochronal heating at various temperatures for $1 \mathrm{~h}$. 


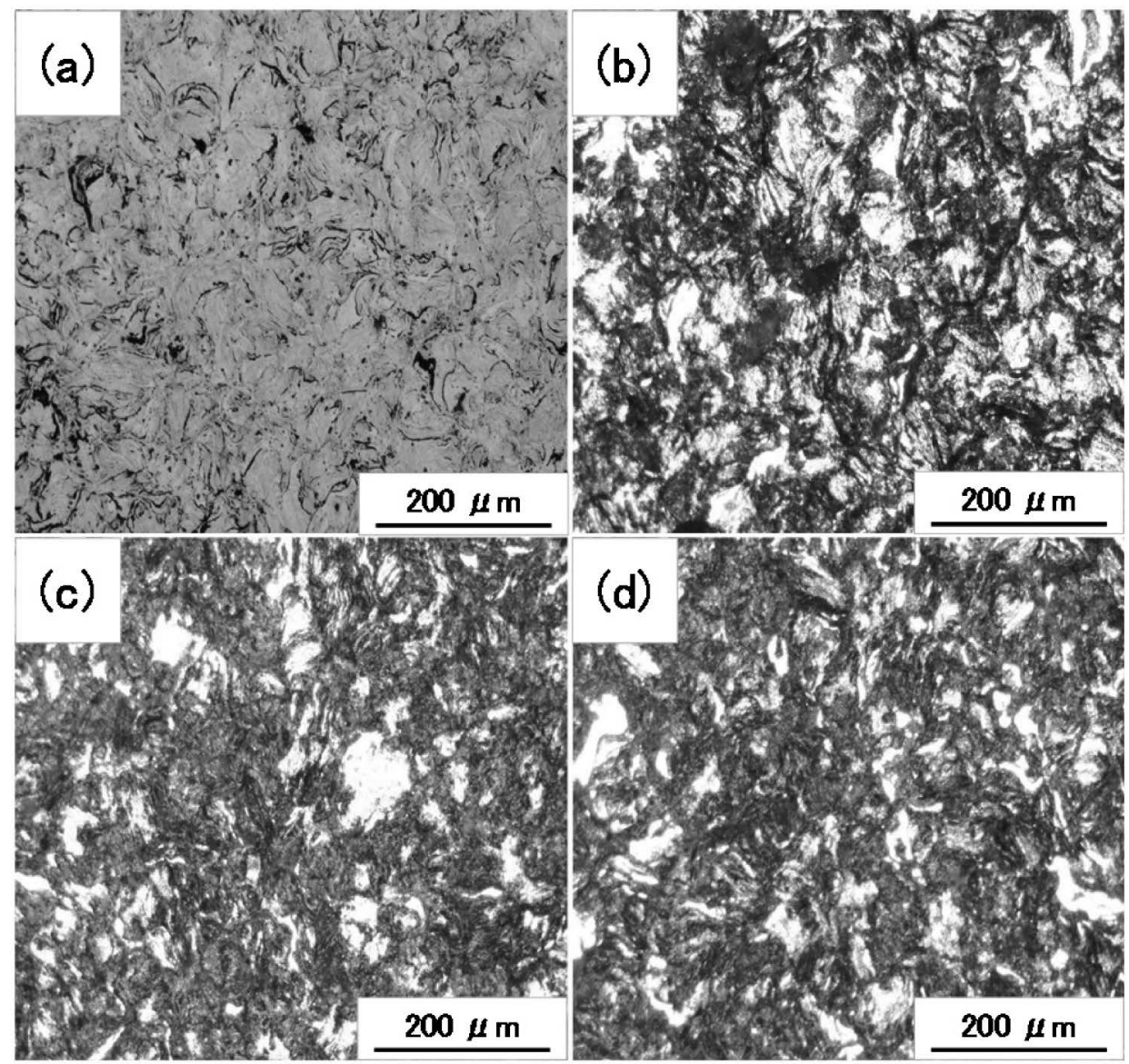

Fig. 3 Optical micrographs showing microstructure of SPS materials fabricated from mechanically milled $32 \mathrm{~h}$ pure Mg powder with addition of $0.50 \mathrm{~g}$ PCA after isochronal heating at various temperatures for $1 \mathrm{~h}$ : (a) as-sintered, (b) $473 \mathrm{~K}$, (c) $523 \mathrm{~K}$ and (d) $573 \mathrm{~K}$.

Table 1 Summary for constituent phases identified by X-ray diffraction in SPS materials fabricated from mechanically milled pure $\mathrm{Mg}$ powder with addition of $0.50 \mathrm{~g}$ PCA after isochronal heating at various temperatures for $1 \mathrm{~h}$.

\begin{tabular}{|c|c|c|c|c|c|c|}
\hline \multirow{2}{*}{$\begin{array}{l}\text { Heating } \\
\text { temp. (K) }\end{array}$} & \multicolumn{6}{|c|}{ Mechanical milling time $(h)$} \\
\hline & 2 & 4 & 8 & 16 & 32 & 64 \\
\hline as-SPS & \multicolumn{6}{|c|}{$\mathrm{Mg}$} \\
\hline \multirow{2}{*}{473} & \multicolumn{5}{|c|}{$\mathrm{Mg}, \mathrm{MgO}, \mathrm{MgH}_{2}$} & \\
\hline & \multicolumn{5}{|c|}{$\mathrm{Mg}(\mathrm{OH})_{2}$} & \\
\hline \multirow{2}{*}{523} & \multicolumn{5}{|c|}{$\mathrm{Mg}, \mathrm{MgO}, \mathrm{MgH}_{2}$} & \\
\hline & \multicolumn{5}{|c|}{$\mathrm{Mg}(\mathrm{OH})_{2}$} & \\
\hline \multirow{2}{*}{573} & \multicolumn{5}{|c|}{$\mathrm{Mg}, \mathrm{MgO}, \mathrm{MgH}_{2}$} & \\
\hline & & & & & $\mathrm{Mg}(\mathrm{OH})_{2}$ & \\
\hline
\end{tabular}

純マグネシウム以外に $\mathrm{MgO}$ および $\mathrm{MgH}_{2}$ が生成されていた。 一方，MM 8h, MM 16hおよびMM $32 \mathrm{~h}$ SPS 材は，純マグネ シウム, $\mathrm{MgO}, \mathrm{MgH}_{2}$ のほかに $\mathrm{Mg}(\mathrm{OH})_{2}$ の生成が認められた。 また, $573 \mathrm{~K} て ゙$ 加熱したMM 2h, MM 4h, MM 8h, MM 16h お よびMM $64 \mathrm{~h}$ SPS 材は，純マグネシウム， $\mathrm{MgO}$ および $\mathrm{MgH}_{2}$ で構成されていたが，MM $32 \mathrm{~h} \mathrm{SPS}$ 材は，473K および $523 \mathrm{~K}$ で加熱したSPS 材と同様に $\mathrm{Mg}(\mathrm{OH})_{2}$ の生成も認められた。 いずれの SPS 材からも共通の化合物として $\mathrm{MgO}$ および $\mathrm{MgH}_{2}$ の生成が認められたことから, 硬さへの寄与は, $\mathrm{MgO}$ およ び $\mathrm{MgH}_{2}$ が支配的と考えられる。さらに, これらの結果は, $\mathrm{MM}$ 処理時間と熱処理温度により, $\mathrm{Mg}(\mathrm{OH})_{2}$ の生成の有無 を制御できることを示唆している。また, MM処理が長時間
のSPS材ほど硬さは，高い值を示すと予測したが，MM $32 \mathrm{~h}$ SPS材よりも MM 64h SPS 材の方が低い值を示した。詳細な 理由については不明だが, Table 1 より MM $32 \mathrm{~h}$ とM $64 \mathrm{~h} の$ 構成相の違いから $\mathrm{Mg}(\mathrm{OH})_{2}$ の有無が関与していることが考 えられる。

Fig. 3 に等時加熱（1h）後のMM 32 h SPS 材の組織を光学 顕微鏡で観察した結果を示す。加熱前のSPS材（a）は, 全 体がコントラストのない組織を呈していた。しかし， $473 \mathrm{~K}$ で加熱するとコントラストが現れ, 白い領域以外に黒い領域

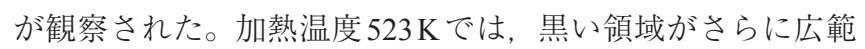
囲で認められ, 加熱温度 $573 \mathrm{~K} て ゙ も 523 \mathrm{~K}$ と同様の組織が観 察された。マイクロビッカース硬度計を用いて白い領域と黒 い領域のそれぞれの硬さを測定した結果, 白い領域は $50 \mathrm{HV}$ 前後を示し，黒い領域は100～200 HVを示した。これらの結 果から, それぞれの領域は, 白い部分がマトリックスの純マ グネシウムで，黒い部分が固相反応によって生成した化合物 相に対応していると推察した。この結果は, 加熱温度が上昇 するにつれて, 固相反応が促進され, より多くの化合物相が 生成していることを示唆している。電子線マイクロアナライ ザーを用いたSPS材表面の元素分析や定量分析および透過型 電子顕微鏡を用いた構造解析が今後の課題である。

\section{2 等温加熱の影響}

3.1 節から明らかになった硬さの值が最も顕著に増加した $523 \mathrm{~K}$ で等温加熱後, 室温で硬さを測定した結果を Fig. 4 に示 す。なお，横軸のAs-sintered と $473 \mathrm{~K} に$ 連続性はない。 MM 


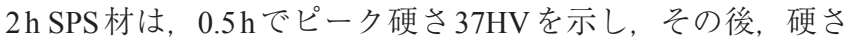
は一定值を示した。この值は，MM処理前の純マグネシウム から作製したSPS 材よりもわずかに高い值である。MM $4 \mathrm{~h}$ SPS 材は, 加熱 $1 \mathrm{~h}$ でピーク硬さ $50 \mathrm{HV}$ を示し，その後，緩や かに軟化した。一方，MM 8h, MM16h およびMM 64h SPS 材 は，加熱 $2 \mathrm{~h}$ でピーク硬さを示し，その後，顕著な軟化傾向は 認められなかった。最も顕著な硬化挙動を示したのは，MM $32 \mathrm{~h} \mathrm{SPS}$ 材で, 加熱 $1 \mathrm{~h} て ゙ 86 \mathrm{HV}$ を示し (Fig. 1), その後, 緩 やかに硬さは高くなり，8hでピーク硬さ $91 \mathrm{HV}$ を示した。こ の值は，同温度 $(523 \mathrm{~K})$ で時効したWE54A合金 ${ }^{9)}$ の時効硬 化能（約 $\Delta 20 \mathrm{HV} ）$ より高い $(\Delta 43 \mathrm{HV})$ 。また, WE54A 合金 ${ }^{9)}$ は，明瞭な過時効を示すが，本研究で作製したSPS材は，加 熱時間が経過しても $8 \mathrm{~h}$ までは顕著な軟化が認められず，優

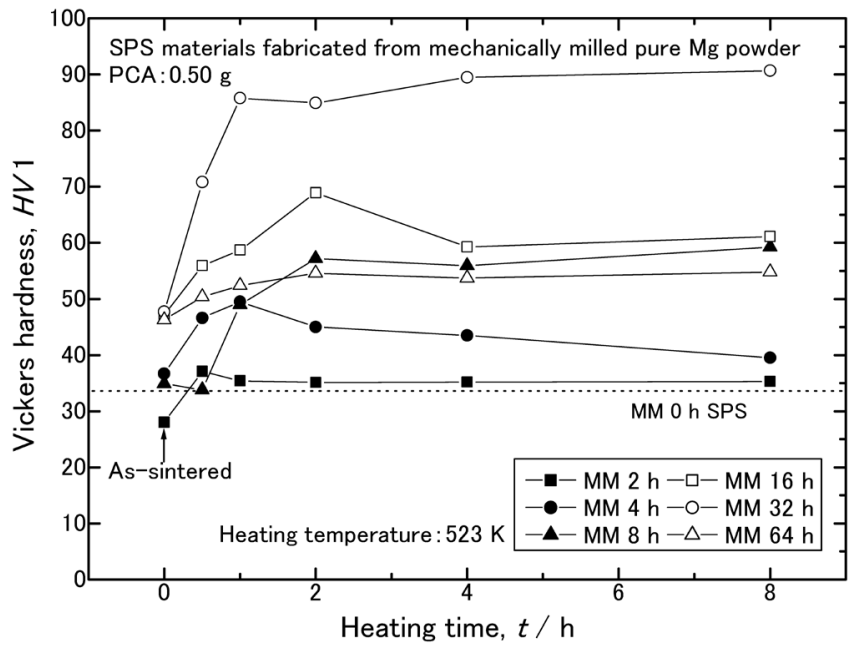

Fig. 4 Changes in Vickers hardness for SPS materials fabricated from powders produced by different mechanically milled time with addition of $0.50 \mathrm{~g}$ PCA as a function of heating time at $523 \mathrm{~K}$.

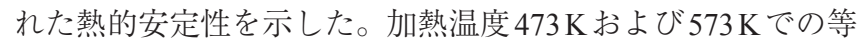
時加熱に対する硬さの変化は, Fig. 4 と同様の傾向を示した。

明瞭な硬化挙動を示したMM32h SPS 材の等温加 熱 $(523 \mathrm{~K})$ 後のX線回折パターンを Fig. 5 に示す。加熱前の 粉末およびSPS材では，純マグネシウムのみが同定 ${ }^{30)}$ され た。一方で， $0.5 \mathrm{~h}$ 加熱されたSPS材では，純マグネシウムの 回折ピーク以外に $\mathrm{MgO}^{31)}, \mathrm{MgH}_{2}{ }^{32)}$ および $\mathrm{Mg}(\mathrm{OH})_{2}{ }^{33)}$ の回 折ピークが同定された。特に, $\mathrm{MgO}$ からの回折ピーク強度 は, 他の化合物の回折ピーク強度より高かった。また, 加熱 時間が長くなるにつれて $\mathrm{MgH}_{2}$ および $\mathrm{Mg}(\mathrm{OH})_{2}$ からの回折 ピーク強度が高くなった。しかしながら, 硬さの值は $\mathrm{MgH}_{2}$ および $\mathrm{Mg}(\mathrm{OH})_{2}$ の回折ピーク強度に対応した増加は認めら れなかった。したがって, Fig. 4 に示した硬化挙動の主な要 因は，固相反応によって生成する $\mathrm{MgO}$ が支配的であると考 えられる。

\section{4. 考察}

\section{1 加熱に伴う化合物の生成量}

3.1 節および 3.2 節にそれぞれ示した等時加熱および等温加 熱の結果からSPS材の硬化現象は, 固相反応によって生成す る化合物の寄与が明らかにされた。各反応生成物が硬さに寄 与する割合を定量的に見積もった結果を Fig. 6に示す。まず, Fig. 6(a) に各SPS材の等温加熱 $(523 \mathrm{~K})$ 後に生成した $\mathrm{MgO}$ のX線回折ピーク強度を純マグネシウムの回折ピーク強度 で除した值を回折ピーク強度比として示す。この回折ピー ク強度比（強度比）を相対的な $\mathrm{MgO}$ の生成量と仮定した ${ }^{34)}$ 。 ここで $\mathrm{MgO}\left(2 \theta=42.916^{\circ},(200)\right)$ と純マグネシウム $(2 \theta$ $\left.=36.619^{\circ},(10 \overline{1} 1)\right)$ のそれぞれの回折ピーク強度は最も相対 強度が高い角度を選択した。MM $2 \mathrm{~h}$ SPS 材は， $0.5 \mathrm{~h} の$ 加熱 で強度比 $3.2 \%$ を示したが，その後，強度比は，0\%であつ た。一方, MM 4h およびMM 64h SPS 材は, $0.5 \mathrm{~h} の$ 加熱以後, 強度比は一定值（約 5\%）を示し，MM $8 \mathrm{~h}$ およびMM $16 \mathrm{~h}$

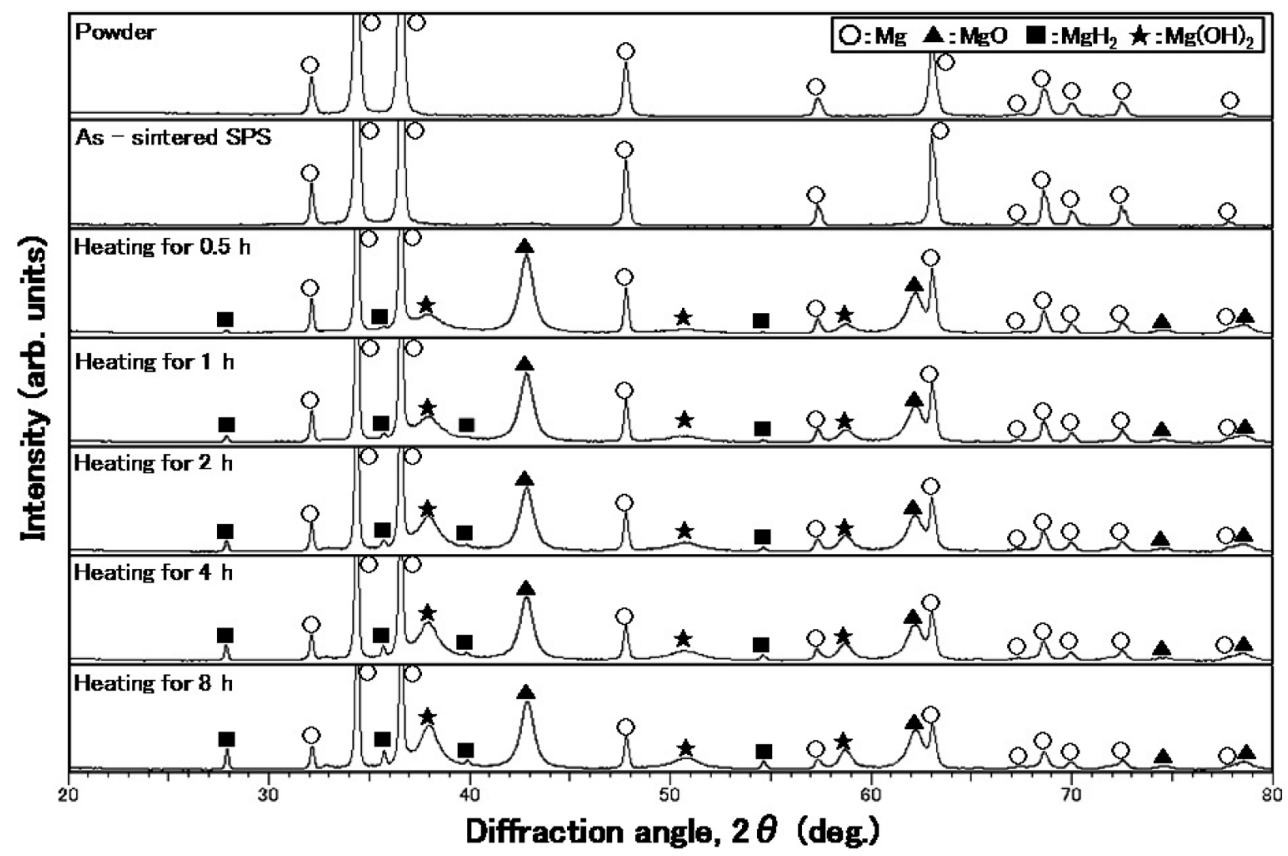

Fig. 5 X-ray diffraction patterns recorded from SPS materials fabricated from mechanically milled $32 \mathrm{~h}$ pure Mg powder with addition of $0.50 \mathrm{~g}$ PCA after isothermal heating at $523 \mathrm{~K}$ up to $8 \mathrm{~h}$. 

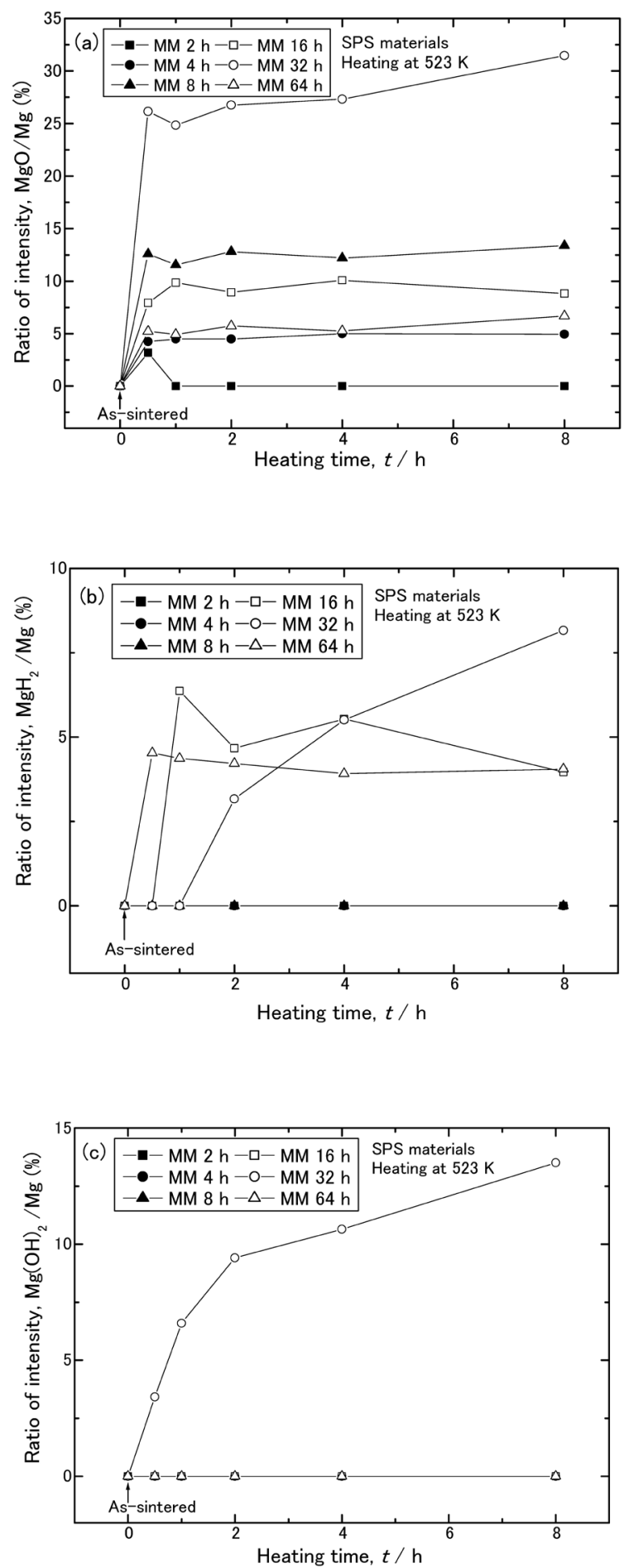

Fig. 6 X-ray intensity ratios of SPS materials fabricated from mechanically milled pure $\mathrm{Mg}$ powder with addition of $0.50 \mathrm{~g}$ PCA after heating at $523 \mathrm{~K}$ up to $8 \mathrm{~h}$ : (a) $\mathrm{MgO}$, (b) $\mathrm{MgH}_{2}$ and (c) $\mathrm{Mg}(\mathrm{OH})_{2}$.

SPS 材は, $0.5 \mathrm{~h}$ の加熱後, 強度比は約 $10 \%$ を示した。特に, MM $32 \mathrm{~h} \mathrm{SPS}$ 材は， $0.5 \mathrm{~h}$ の加熱で強度比 $26.1 \%$ を示し，その 後，わずかに増加し，8hの加熱で31.5\%を示した。高い強 度比を示したMM $8 \mathrm{~h}$ SPS 材およびMM $32 \mathrm{~h}$ SPS 材は, Fig. 4 に示したように優れた硬化能（MM 8h SPS 材： $\Delta 32 \mathrm{HV}, \mathrm{MM}$ $32 \mathrm{~h} \mathrm{SPS}$ 材: $\Delta 43 \mathrm{HV})$ が得られている。ここで, MM処理 時間を変化させて作製したSPS材でも同時に強度比が高いほ ど，加熱に対する硬化能も優れていた。

次に, Fig. 6(b) に各SPS材の等温加熱 $(523 \mathrm{~K})$ 後に生成
した $\mathrm{MgH}_{2}$ の X線回折ピーク強度 $\left(2 \theta=27.946^{\circ},(110)\right)$ を純 マグネシウムの回折ピーク強度 $\left(2 \theta=36.619^{\circ}, \quad(10 \overline{1} 1)\right)$ で除 した值を回折ピーク強度比（強度比）として示す。この回折 ピーク強度比を相対的な $\mathrm{MgH}_{2}$ の生成量と仮定した ${ }^{34)}$ 。回折 ピーク強度の取り扱いは, $\mathrm{MgO}$ の時と同様に最も相対強度 が高い角度を選択した。MM 2h, MM 4h およびMM 8h SPS 材は, 加熱時間に関わらず, 強度比 $0 \%$ を示した。固相反応 によって生成した化合物をまとめたTable 1 に示したように, X線回折パターンからは $\mathrm{MgH}_{2}$ の生成が認められているが, $\mathrm{MgH}_{2}$ からの回折ピーク強度がマグネシウムの回折ピーク強 度と比較し, 非常に小さい值を示したため, 生成量としては 0 として見積もられている。MM 16h およびMM 64h SPS 材 は, $1 \mathrm{~h}$ の加熱以後, 強度比は一定值（約 5\%) を示した。一方, MM $32 \mathrm{~h} \mathrm{SPS}$ 材は, 加熱時間が長くなるほど, 強度比が大き くなり， $8 \mathrm{~h}$ の加熱で $8.2 \%$ を示した。

最後に, Fig. 6(c) に各SPS材の等温加熱 $(523 \mathrm{~K})$ 後に生 成した $\mathrm{Mg}(\mathrm{OH}){ }_{2}$ のX線回折ピーク強度 $\left(2 \theta=38.016^{\circ},(101)\right)$ を純マグネシウムの回折ピーク強度 $\left(2 \theta=36.619^{\circ},(1011)\right)$ で除した值を回折ピーク強度比（強度比）として示す。こ の回折ピーク強度比を相対的な $\mathrm{Mg}(\mathrm{OH})_{2}$ の生成量と仮定し た ${ }^{34)}$ 。回折ピーク強度の取り扱いは, $\mathrm{MgO}$ の時と同様に最 も相対強度が高い角度を選択した。MM $2 \mathrm{~h}, \mathrm{MM} 4 \mathrm{~h}, \mathrm{MM} 8 \mathrm{~h}$, MM 16h およびMM 64h SPS 材は, $\mathrm{MgH}_{2}$ と同様に回折ピー ク強度がマグネシウムと比較して非常に小さかったために, 生成量は 0 として見積もられた。一方で, MM $32 \mathrm{~h} \mathrm{SPS}$ 材は, 加熱時間が長くなると共に強度比が高くなり, $8 \mathrm{~h} の$ 加熱で $13.5 \%$ を示した。

$\mathrm{MgH}_{2}$ および $\mathrm{Mg}(\mathrm{OH})_{2}$ の生成量が 0 と見積もられた $\mathrm{SPS}$ 材 でも, Fig. 4 に示したように等温加熱に対して硬化現象が認 められていることから, 硬化現象を発現させた主な要因は 固相反応によって生成される $\mathrm{MgO}$ に起因していると考えら れる。また, Fig. 6(a)〜 ( c) の結果から $\mathrm{MgO}_{2} \mathrm{MgH}_{2}$ および $\mathrm{Mg}(\mathrm{OH})_{2}$ の同時生成によって硬化現象がもたらされた可能 性が示されており, 硬化現象との関係について詳細を調べる 必要がある。

\section{2 等温加熱に対する高硬度化}

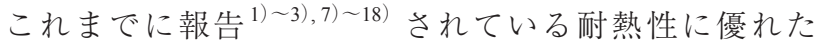
時効硬化型マグネシウム合金の中で, ここでは一例とし て Mg-15Gd (mass\%) 合金の $473 \mathrm{~K} て ゙ の$ 時効硬化曲線 ${ }^{35)}$ を Fig. 7 に示し，本研究で作製したSPS材と比較する。ただし， Mg-15Gd (mass\%) 合金の時効硬化挙動は，過飽和固溶体か ら相分解に伴う熱活性化過程で生じる析出をべースにした硬 化現象であり, 一方, 本研究の硬化挙動は加熱中に熱力学 的に安定な化合物相を固相反応によって生成することで生 じる硬化現象であるため, 単純な比較はできない。合金鋳 塊を $773 \mathrm{~K} て ゙$ 溶体化処理後, 水焼入れ状態の硬さは $60 \mathrm{HV}$ 示し, ピーク硬さは約 60 時間で得られ, その值は $105 \mathrm{HV}$

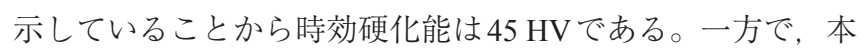
研究でMM-SPSプロセスから作製したSPS材では, Fig. 1 か ら $473 \mathrm{~K}$ で加熱したMM 2h, MM 4h, MM 16h およびMM $32 \mathrm{~h}$ SPS材の硬さは, 加熱前のSPS材と比較してそれぞれ約 $5 \mathrm{HV}$ 高い值を示し, MM 8h およびMM $64 \mathrm{~h}$ SPS 材では, それぞ れ約 $15 \mathrm{HV}$ 高い值が得られた。したがって, 溶解鋳造プロ セスで作製された $\mathrm{Mg}-15 \mathrm{Gd}$ 合金より硬化能は低かった。し 


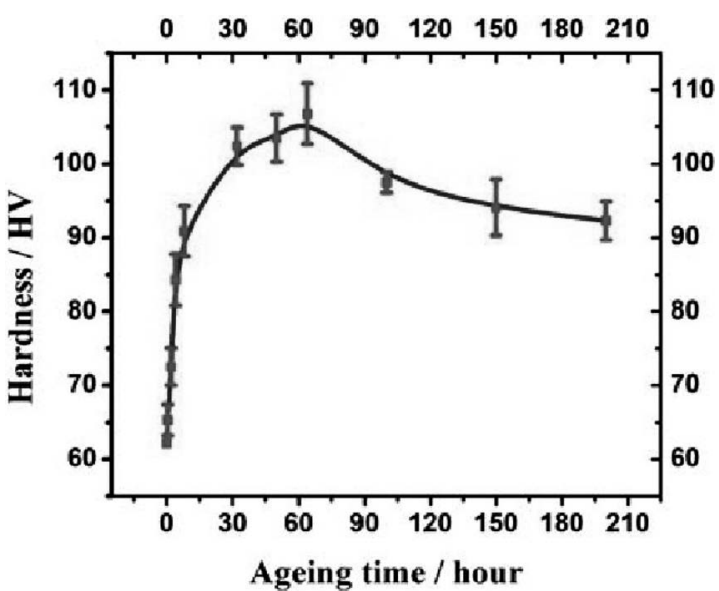

Fig. 7 Age-hardening curve of $\mathrm{Mg}-15$ mass\%Gd alloy after solution treated at $773 \mathrm{~K}$ in a sulfur atmosphere for $2 \mathrm{~h}$ and then was quenched in water, then ageing at $473 \mathrm{~K}^{35)}$

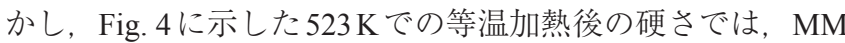
$32 \mathrm{~h} \mathrm{SPS}$ 材が $1 \mathrm{~h}$ の加熱で $86 \mathrm{HV}$ を示し，その後，緩やかに 硬さは上昇し， $8 \mathrm{~h}$ の加熱で最高硬さ $91 \mathrm{HV}$ を示したことか ら固相反応による硬化能は $43 \mathrm{HV}$ である。前述した時効硬 化能 ${ }^{35)}$ と本研究で得られた硬化能は, 本研究の加熱温度が $50 \mathrm{~K}$ 高いにもかかわらず，同程度の硬化能を示した。これは， 本研究で作製したSPS 材が固相反応を誘起する温度が一般的 な時効温度 $(423 \mathrm{~K} や 473 \mathrm{~K})$ と比べて高いことが本研究より 示され，熱的安定性を考えた場合，MM-SPS材に熱処理を施 した方が優位性を示す結果となっている。さらに，ピーク硬 さに到達する時間も溶解鋳造プロセスと時効熱処理を組み合 わせて作製された $\mathrm{Mg}-15 \mathrm{Gd}$ 合金 ${ }^{35)} よ り$ 本研究で作製した材 料の方が一桁以上短く，熱処理時間を大幅に短縮できる可能 性が示された。さらに $\mathrm{Mg}-15 \mathrm{Gd}$ 合金 ${ }^{35)}$ ではピーク硬さに達 した後，過時効を示すが，本プロセスで作製したSPS材は高 融点 $(3125 \mathrm{~K})$ の $\mathrm{MgO}$ が固相反応で生成するため, これら

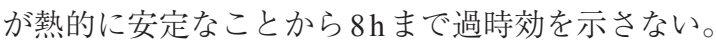

WE54A 合金 ${ }^{9)}$ との比較では, 本研究で作製したバル ク材の $523 \mathrm{~K}$ での硬化能は, 同温度 $(523 \mathrm{~K})$ で時効した

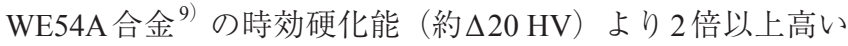
值（ $\Delta 43 \mathrm{HV} ）$ を示した。また，同温度で時効したWE54A合 金 ${ }^{9)}$ は, $10 \mathrm{~h}$ 以上の熱処理で硬化現象が開始するが，本研究 で作製したSPS材は短時間（1h）の加熱で硬化現象が認めら れている。さらに，WE54A 合金 ${ }^{9)}$ は，明瞭な過時効を示す

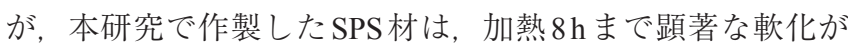
認められず，優れた熱的安定性を示している。一般的に過飽 和固溶体からの相分解に伴う熱活性化過程で生じる析出の場 合，時効時間の経過とともに過時効する。これは，析出物が 時間経過とともに粗大化し，オロワン強化機構が働かなくな ることが要因の一つとして知られている。本研究結果をこの 内容で説明した場合, $\mathrm{MgO}$ の融点が高いため時効時間の経 過とともに $\mathrm{MgO}$ 粒子の大きさが粗大化しないことが考えら れる。

したがって，MM-SPS プロセスで作製したSPS 材に加熱を 施した加工熱処理によって固相反応が誘起され，それに伴っ て生じる硬化挙動は, 硬化能, ピーク硬さに達する時間およ び過時効現象が生じないといった既存の溶解鋳造法と加工熱
処理を組み合わせたプロセスでは得られない特異な現象を発 現することが明らかとなり，優れた熱的安定性を示す材料が 創製できる可能性が示された。過飽和固溶体からの析出によ る時効硬化挙動と固相反応により生成する化合物による硬化 挙動は，同じ固相-固相による相変態をべースにしているが, 各分散相のサイズや熱的安定性には大きな違いがあると考え られ，透過型電子顕微鏡を用いた詳細な組織観察が今後の課 題である。

\section{5. 結言}

本研究では熱的安定性に優れた純マグネシウムを創製する ことを目的に, MM処理の際にミリング助剤として安価かつ ユビキタス元素であるステアリン酸を $0.50 \mathrm{~g}$ 添加 ${ }^{28)}$ し, 各 MM処理時間から得られたMM粉末をSPS装置により固化成 形した ${ }^{28)}$ 。作製したSPS材に対して種々の熱処理を行い, 硬 さ試験，X線回折および光学顕微鏡による組織観察を行った 結果, 以下の知見を得た。

（1）各SPS材を加熱することによって硬化現象が発現し

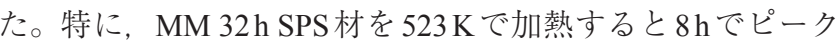
硬さを示し, その值は $91 \mathrm{HV}$ を示し, その硬化能は $\Delta 43 \mathrm{HV}$ であった。この值は，耐熱性に優れたマグネシウム合金とし て知られているWE 54A 合金 ${ }^{9)} や \mathrm{Mg}-15 \mathrm{Gd}$ 合金 ${ }^{35)}$ の時効硬 化能より高いレベルであった。

(2) 各SPS材の硬さは，等時加熱中に短時間でピーク硬さ に達し，8hまで加熱しても過時効を示さず，優れた熱的安 定性を示した。

（3）MM-SPSプロセスで作製したSPS材を加熱すること で固相反応が誘起され, 生成した化合物相 $\left(\mathrm{MgO}, \mathrm{MgH}_{2}\right.$, $\left.\mathrm{Mg}(\mathrm{OH})_{2}\right)$ の寄与によって硬化現象がもたらされた。等時 加熱および等温加熱で発現した硬化現象は, $\mathrm{MgO}$ にるる寄 与が最も大きかった。

以上の結論から, 純マグネシウムにMM-SPS プロセスを適 用することによって，加熱中に時効硬化を発現させ高温特性 を大幅に改善できることが示された。

\section{参 考 文 献}

1) L. L. Rokhlin: Phys. Met. Metallogr., 54 (1982), 96-100.

2) L. L. Rokhlin: Phys. Met. Metallogr., 55 (1983), 98-103.

3) L. L. Rokhlin: Magnesium Alloys Containing Rare Earth Metals, Taylor \& Francis, (2003), 97-157.

4）諸住正太郎：名古屋工業技術試験所報告，2（1953），255-260

5) 大森梧郎, 松尾 茂, 麻田 宏：軽金属, 20 (1970), 490-497.

6) G. Omori, S. Matsuo and H. Asada: JIM, 16 (1975), 247-255.

7）鎌土重晴，岩澤 秀，大内清明，小島 陽，二宮隆二：軽金属, 42 (1992), 727-733.

8）岩澤 秀, 根岸祐司, 鎌土重晴, 小島 陽, 二宮隆二：軽金属, 44 (1994), 3-8.

9) ASM International: Magnesium and Magnesium Alloys, (1999), 243

10）根岸祐司, 岩澤 秀, 鎌土重晴, 小島 陽, 二宮隆二：軽金属, 44 (1994), 549-554.

11）根岸祐司, 西村卓寛, 岩澤 秀, 鎌土重晴, 小島 陽, 二宮隆 二：軽金属，44（1994），555-561.

12) 小島 陽:軽金属, 58 (2008), 526-548.

13) K. Oh-ishi, R. Watanabe, C. L. Mendis and K. Hono: Mater. Sci. Eng. A, 526 (2009), 177-184.

14) J. Jayaraj, C. L. Mendis, T. Ohkubo, K. Oh-ishi and K. Hono: Scr. Mater., 63 (2010), 831-834.

15) S. W. Xu, K. Oh-ishi, S. Kamado, F. Uchida, T. Homma and K. Hono: Scr. Mater., 65 (2011), 269-272. 
16) T. Nakata, T. Mezaki, R. Ajima, C. Xu, K. Oh-ishi, K. Shimizu, S. Hanaki, T. T. Sasaki, K. Hono and S. Kamado: Scr. Mater., 101 (2015), 28-31.

17）野本朝輝, 柏瀬早季子, 中川恭輔, 久澤大夢, 寺田芳弘：日本 金属学会誌, 82 (2018), 94-101.

18) S. W. Xu, K. Oh-ishi, S. Kamado, H. Takahashi and T. Homma: Mater. Sci. Eng. A, 542 (2012), 71-78.

19) M. Kubota: J. Alloys Compd., 434-435 (2007), 294-297.

20) 久保田正広：軽金属, 62 (2012), 424-428.

21）大野卓哉，久保田正広：軽金属，59（2009），659-665.

22）大野卓哉, 久保田正広：粉体および粉末治金, 57（2010）, 327-332.

23）大野卓哉, 久保田正広：軽金属, 60（2010）, 647-653.

24）久保田正広：紛体および粉末治金，64（2017），265-274.

25）铇田正雄：粉体工学会誌, 30（1993）, 790-804.

26) 大森 守：紛体および粉末治金, 45（1998），1055-1060.
27) 大森 守：まてりあ, 39(2000)，54-57.

28）久保田正広，萩野敏基：軽金属，69（2019），242-248.

29) S. Hwang, C. Nishimura and P. G. McCormick: Mater. Sci. Eng. A, 318 (2001), 22-33.

30) JCPDS: 35-0821, International Centre for Diffraction Data, (1999), $\mathrm{Mg}$

31) JCPDS: 45-0946, International Centre for Diffraction Data, (1999), $\mathrm{MgO}$.

32) JCPDS: 12-0697, International Centre for Diffraction Data, (1999), $\mathrm{MgH}_{2}$.

33) JCPDS: 07-0239, International Centre for Diffraction Data, (1999), $\mathrm{Mg}(\mathrm{OH})_{2}$

34) C. Suryanarayana and M. G. Norton: X-Ray Diffraction A Practical Approach, Plenum Press, (1998), 223-226.

35) J. K. Zheng, R. Luo, X. Zeng and B. Chen: Mater. Des., 137 (2018), $316-324$. 